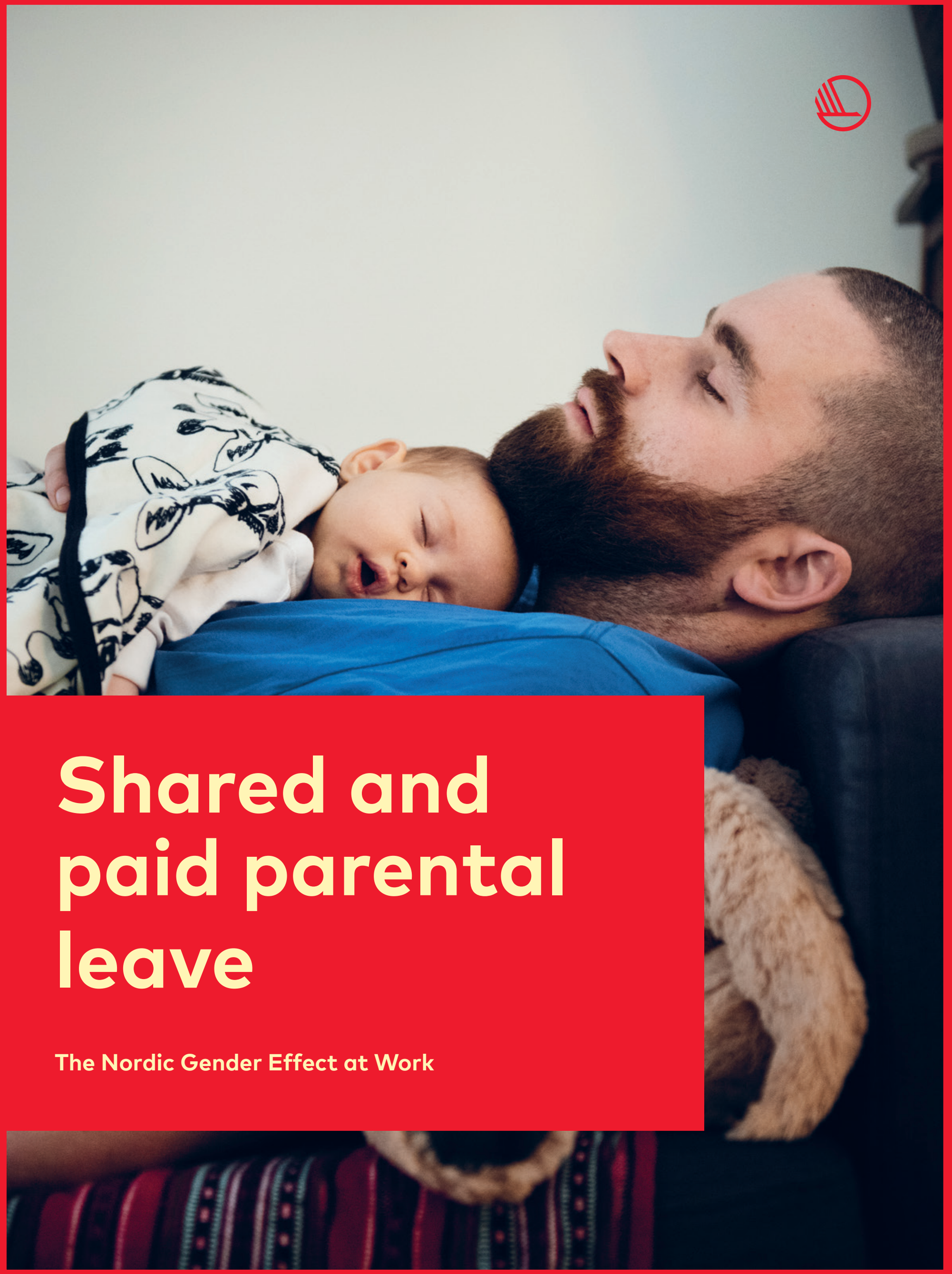




\section{Shared and paid parental leave}

The Nordic Gender Effect at Work

Nord 2019:055

978-92-893-6403-4 (PRINT)

978-92-893-6404-1 (PDF)

978-92-893-6405-8 (EPUB)

http://doi.org/10.6027/NO2019-055

(C) Nordic Council of Ministers 2019

Layout: Mette Agger Tang

Cover photo: Moa Karlberg

Infographics: Essensen

Print: Rosendahls

Printed in Denmark

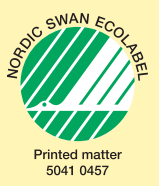

\section{Nordic co-operation}

Nordic co-operation is one of the world's most extensive forms of regional collaboration, involving Denmark, Finland, Iceland, Norway, Sweden, the Faroe Islands, Greenland, and Åland.

Nordic co-operation has firm traditions in politics, the economy, and culture. It plays an important role in European and international collaboration, and aims at creating a strong Nordic community in a strong Europe.

Nordic co-operation seeks to safeguard Nordic and regional interests and principles in the global community. Shared Nordic values help the region solidify its position as one of the world's most innovative and competitive.

\section{Nordic Council of Ministers}

Nordens Hus

Ved Stranden 18

DK-1061 Copenhagen

www.norden.org

Download Nordic publications at www.norden.org/nordpub 
Investments in gender equality in the labour market have made the Nordic region one of the most prosperous areas of the world. The share of women who work in the Nordic countries is larger than the global average, which is partly the effect of commitments to equal workplaces, subsidised childcare and generous parental leave. With The Nordic Gender Effect at Work briefs, the Nordic region seeks to share its collective experience in promoting gender equality at work, and enable more knowledge sharing and progress towards the UN's 2030 Agenda for Sustainable Development. 

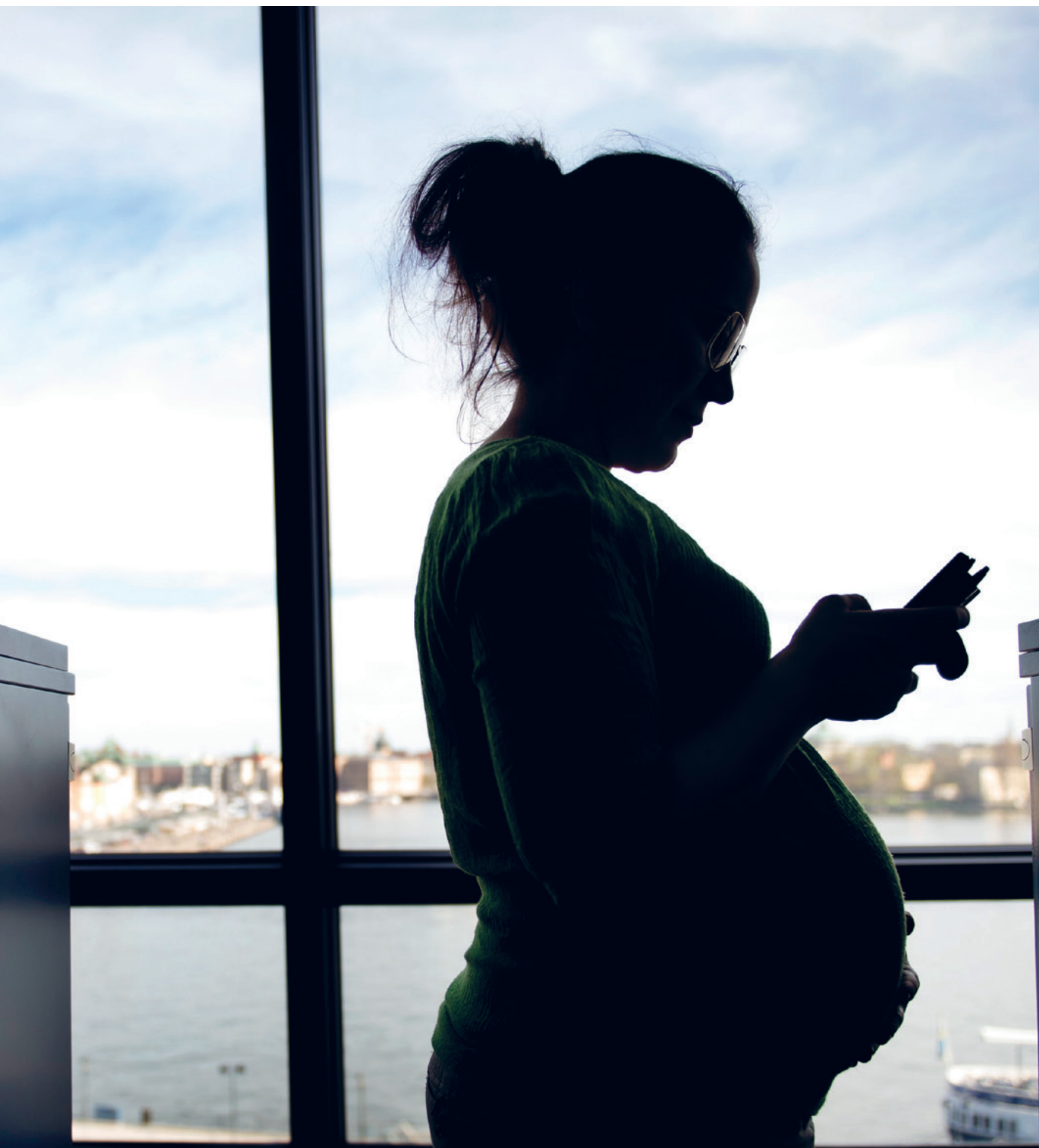

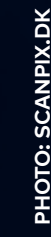




\section{Introduction}

Only half of women in the world engage in paid work. Many do so in poor working conditions with low pay, without access to maternity protection or parental leave. Childcare is often unreliable or unaffordable, and violence and sexual harassment are a reality of many working women's day. These exclusions are a violation of women's basic human rights. What is more, gender inequality at work is economically inefficient and ultimately costly for companies and countries alike.

Promoting gender equality at work is thus not only the right thing to do, but the smart thing to do. The Nordic region can be seen as a case in point. Combined, the five Nordic countries have come to represent the 11th largest economy in the world, not despite their policy commitment to gender equality and social justice, but because of it. Today the Nordic countries are known as financially strong welfare states with good living conditions. However, this has not always been the case.

In the past 100 years, women in the Nordic region have transitioned from living under husbands' guardianships to being financially independent, from not having the right to vote to holding the highest offices in society. The labour movement and the women's rights movement played important roles in making these changes happen, and helped pave the way for new legislation together with progressive policymakers. Descriptions of life in the Nordic countries often reference 'the Nordic model', which is characterised by a political ambition to reduce inequalities and by effective cooperation between the social partners and with collective bargaining in the labour market. Building on this, the Nordic countries have introduced a range of policies since the 1960s that facilitate women's engagement in paid work, as part of a broader policy agenda to advance gender equality and social justice.
Today the Nordic countries lie ahead of the curve on women's participation in the labour force. A significant policy to reach this position was high quality, subsidised childcare for all. The policy incentivised mothers to remain in the workforce after having children, and created a plethora of educational opportunities and jobs in the childcare industry. Enabling and promoting shared parental leave has been another key to prosperity for the Nordics. The countries have even encouraged paternity leave, which sets a path towards more involved fatherhood and happier and healthier families. Nordic employers across industries also recognise that flexible work arrangements do not impede productivity, but rather reduces stress and enables both working women and men to attend to their family responsibilities. It is part of a broader Nordic policy agenda of seeing rights and productivity as two sides of the same coin.

Despite a strong and consistent focus, there is more work to be done. Notably the Nordic countries are grappling with a resilient gender pay gap and a labour market with high levels of occupational segregation. The region does not have all the answers, and in a number of areas (occupational sex-segregation being a case in point) countries in other regions are performing better. The Nordic governments are committed to playing their part in achieving the UN's Sustainable Development Goals (SDGs) by 2030, and seek to enable international knowledge sharing and facilitate a collective improvement in the stride for gender equality.

This brief focuses on parental leave. The Nordic Gender Effect at Work series include briefs on subsidised childcare for all; shared and paid parental leave; flexible work arrangements; and leadership and equal opportunities at work. 

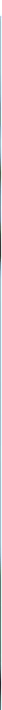

soling

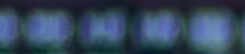

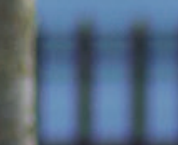

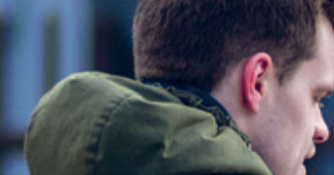

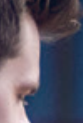

tald

ation

aryos

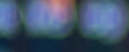

80

4
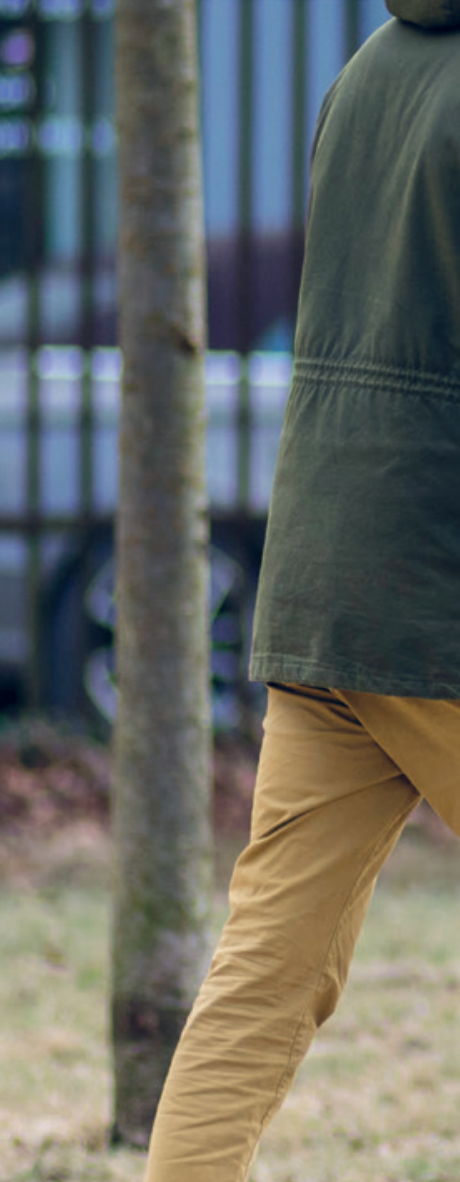

48
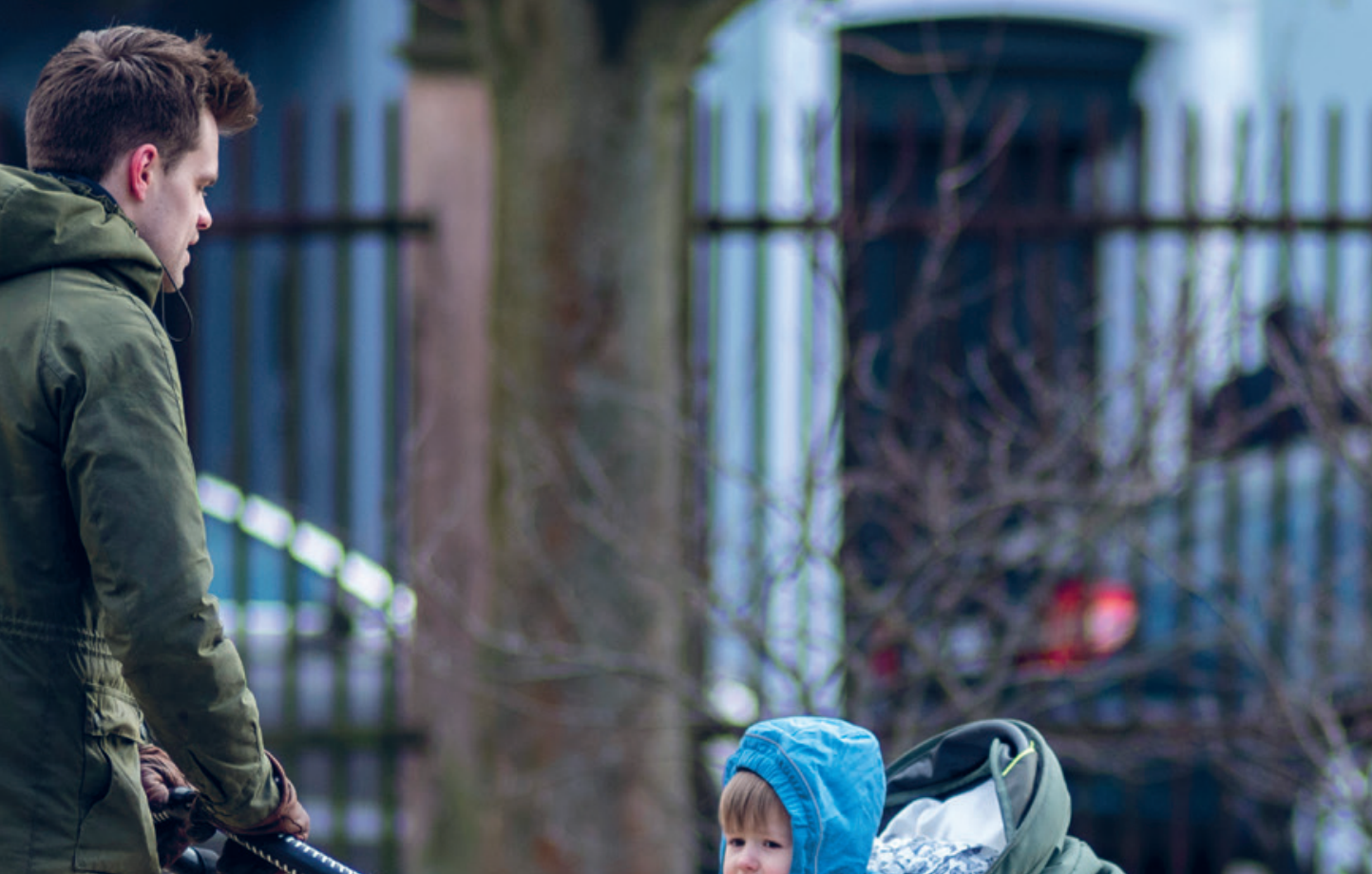

$3 \times 14$

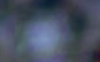

4.

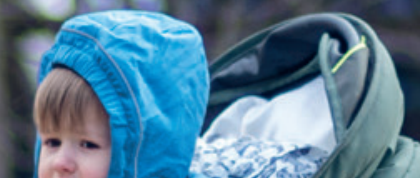

$\frac{1}{4 x^{2}}$
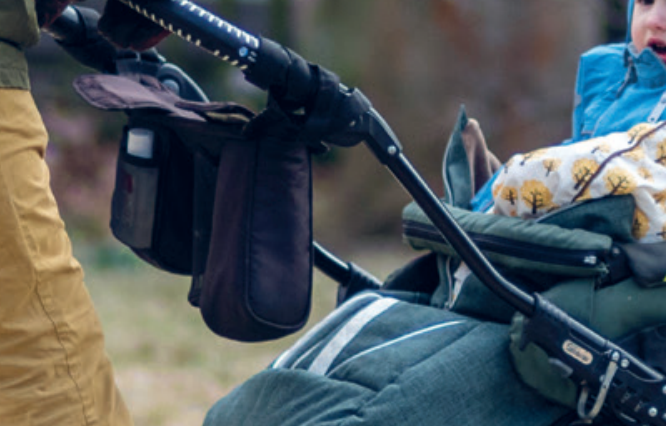

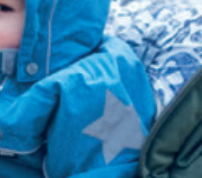

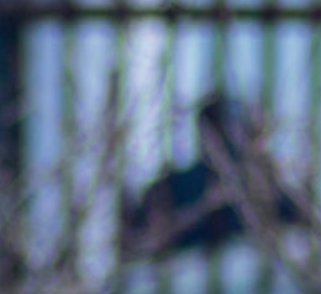

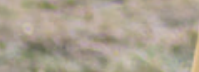
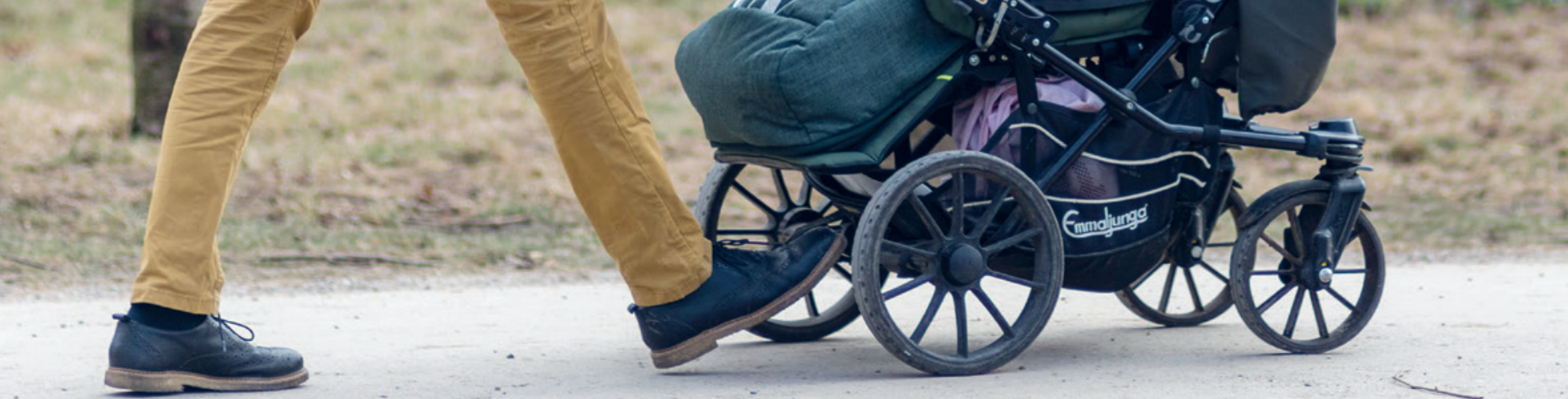
200000 


\title{
Shared and paid parental leave
}

\author{
Both mothers and fathers are entitled to paid parental leave in the \\ Nordic countries. In order to promote and facilitate gender equality \\ at home and in the labour market, efforts have been made at the \\ political level to encourage parents to divide the leave time equally. \\ These efforts have yielded results: Nordic fathers take more paren- \\ tal leave than fathers anywhere else in the world.
}

This brief explains how Nordic parental leave schemes are designed and what sets them apart in an international context.

Parental leave enables working parents to stay home and take care of their young children. Traditionally, mothers have stayed home with their children while their spouses have gone to work. The Nordic countries have seen it as important to enable women to provide financially for themselves and their children. Women's empowerment and self-sufficiency has been a priority. Men's involvement in childcare and unpaid work has also been a policy priority, based on the understanding that it is good for children, good for parents and good for society. As such, they have been at the forefront of introducing longer, paid parental leave that can be shared between the parents. Sweden currently offers the longest period of paid parental leave in the Nordic region, 69 weeks per child, and Iceland the shortest, 39 weeks.

At the global level, there is great variation in parents' right to parental leave. Many OECD countries offer shorter parental leave periods than the Nordic countries, and eleven of the thirty-five OECD member states do not guarantee parents paid leave at all. These include the United States, where national law gives mothers the right to 12 weeks of unpaid leave. Although some states and employers provide more generous protections, the lack of universal paid parental leave makes it complicated for many US parents (and parents from other countries with insufficient leave) to combine work and family life.
The Nordic countries encourage both parents to stay home from work with their young children. In recognition of a gender imbalance in the distribution of parental leave, and with the explicit goal of promoting gender equality both at home and in the workplace, the Nordic countries have taken initiatives to increase the rate of paternity leave through campaigns, organisation and quotas.

\section{Organisation and quotas}

In 1974, Sweden became the first country in the world to introduce parental leave that could be split between two parents of a child. Norway followed suit in 1978, lceland in 1981, Denmark in 1984 and Finland in 1985. However, the initiative had only marginal effects, as mothers continued to take much more parental leave than their male partners.

All Nordic countries except Iceland offer a special paternity leave that fathers can take immediately after the birth of a child to stay home with the newborn baby and the mother. In 1993, Norway took an additional step by earmarking some weeks of the allotted parental leave period for the father - a daddy quota. If the fathers do not use the quota, the family loses the weeks reserved for them. Since then, all Nordic countries have experience with daddy quotas. Research shows that men have responded to the introduction and expansion of the quota by taking more parental leave. The quotas have also influenced people's thoughts and attitudes regarding paternity leave. The daddy quota, as well as the shareable part of 
the leave entitlement, can also be used by the other parent in same-sex couples in several Nordic countries.

\section{Equal sharing}

The Nordic countries promote an equal sharing of parental leave between women and men for several reasons. One reason is fairness, and a belief that mothers and fathers should take equal responsibility for their children, and that children have the right to be with both parents. Gender-equal parenting also contributes towards a more gender-equal participation in the labour market. The fact that women take more parental leave than men can still affect their careers negatively in too many cases. An extended absence from work may reduce a person's status and opportunities in the labour market. Thus, when more men take long-term parental leave, the prospects for gender equality in the labour market increase.

Nordic research shows that men who take longer parental leave also take more responsibility at home. They are more involved in the care of their children, have better relationships with them and do more unpaid housework. Importantly the men spend time caring for the child or children alone, after their partner has returned to work. This establishes a more fundamental sense of shared responsibility between parents. Several initiatives have been taken at the political level to encourage parents to share their parental leave more equally, and the efforts have been successful. Over the past 15 years, men's share of the parental leave has increased in all Nordic countries. Iceland, Norway and Sweden are the OECD countries with the most even distribution of parental leave between men and women. However, the work to reach the goal of equal sharing of parental leave and childcare continues, as mothers in the Nordic region, compared to fathers, still spend much more time tending to their young children.

\section{The rules vary across the countries}

The exact design of the national schemes granting the right to paid parental leave varies across the Nordic countries. All Nordic countries have paid parental leave schemes consisting of three parts. In Iceland three months are reserved for each parent and three months can be divided between them. Iceland has the shortest period in which parental benefit is payable: 39 weeks. In Norway, parents are entitled to 49 weeks of leave, where 15 weeks are reserved for each parent and 16 weeks can be shared. At 480 days Sweden has the longest legally granted parental leave among the Nordic countries. Since 2016, the earmarked leave for each parent has been 13 weeks and the remaining 43 weeks can be divided between the parents. In Denmark, parents have a total of 52 weeks of leave with parental benefits. 18 weeks for mothers only, two weeks for fathers and 32 weeks that can be shared. Finnish parents have 53 weeks of leave, and since 2013, Finnish

\section{How it works}

Parental leave is an umbrella term that refers to the right of mothers and fathers to take time off from work to take care of their children. It consists of three parts. Maternity leave is reserved for one parent; and paternity leave for the other. The third part of the parental leave can be shared between the parents as they desire. Different countries allocate different numbers of days to each part.

\section{Getting dads on board}

To encourage men to take parental leave, all Nordic countries have tried to make their parental leave schemes as flexible as possible, for example by extending the timeframe within which the leave can be taken and enabling parents to divide the leave into several shorter periods for both parents. 
fathers are entitled to nine weeks of paternity leave until the child is two years old that cannot be transferred to the mother. The payment rates for parental benefits range from 70 to 100 per cent, and several countries offer longer leave with further reduced pay.

\section{Level of parental benefits}

The Nordic countries have given high priority to the issue of compensation levels and allocate significantly more public funds to parental leave allowances than the OECD average. How much parental leave people take is related to how much compensation they are entitled to. In all Nordic countries, parents are compensated financially for the income they lose during their parental leave. The compensation can be income-related or a fixed amount. The exact level of income-related compensation varies greatly. Norway and Denmark have the highest level of compensation, and Finland the lowest. All Nordic countries except Finland have put a limit on the compensation that can be paid to a parent. There is an apparent correlation between the level of compensation and the amount of parental leave fathers take; fathers in Iceland, Norway and Sweden, where they enjoy among the highest compensation levels, take more parental leave than fathers in other countries worldwice. Conversely fathers take the least amount of parental leave in countries like Australia, France and South Korea, where compensation levels reach less than half of pre-leave income. The Nordic countries have given high priority to the issue of compensation levels and spend more tax money on parental leave allowances than the OECD average.

\section{Parental leave, attitudes and level of education}

The share of parental leave taken by men varies across the Nordic countries. Iceland tops the list with 30 per cent. Sweden follows closely behind with 29 per cent, and in Norway the figure is 20 per cent. Finnish and Danish men account for 11 per cent of all parental leave outtake.

So, which men are most likely to utilise their right and go on parental leave? While the earmarked paternity leave is taken up by men in all sectors of the labour market, fathers are more likely to go on longer-term parental leave when both parents have high levels of education, or when the father has lower or the same income as the mother. The same is true when the father works in the public sector and the mother works in the private sector. Self-employed men and men in management positions have a relatively low prevalence of going on long-term parental leave.

Research shows that attitudes to paternity leave are becoming increasingly positive among parents, the general population and the social partners in all Nordic countries. Many different actors in the labour market are taking initiatives to encourage men to go on parental leave. For

\section{Importance of paid leave}

South Korea grants the longest periods of non-shareable parental leave in the OECD. Each parent is entitled to one year, and it cannot be transferred to the other parent. However, with a compensation rate of 40 per cent of the parent's pre-leave income (significantly lower than in the Nordic countries), men take very little parental leave. Around 90,000 South Korean workers took parental leave in 2016, but only 8.5 per cent of them were men.

\section{The parental leave effect}

Men who go on long-term parental leave in the Nordic countries are more involved in the care of their children throughout their lives. They do more household work and domestic chores, communicate better with their partners about the needs of their children and have a better understanding of their children and partners' daily life. Studies from all over the world, including Denmark, also show that involved fatherhood improves their health status. 
example, some employers offer employees more weeks of paternity leave and higher compensation levels than required by law. In Denmark, several trade unions have included the right to paternity leave where the respective employers have agreed to pay fathers their full salaries if they choose to take the weeks of parental leave that are reserved for them in collective agreements. At present, around 75 per cent of Danish workers benefit from a collective agreement with a built-in earmarked paternity leave, and the Norwegian trade unions and employer associations are strongly in favour of an expanded daddy quota.

\section{Families outside the norm}

Revising the parental leave schemes to make them more inclusive of non-traditional families is a challenge that remains to be solved across Nordic countries. People in the Nordic countries live in a great variety of family constellations, including lesbian, gay, bisexual, transgender and queer (LGBTQ) families and single-parent households. Parental leave schemes are to some extent adapted to include LGBTQ families. For instance, in Denmark and Norway, a mother's female partner has the same rights to parental leave as a father in a heterosexual couple. However, for the most part, Nordic family benefits systems are built around the notion of heterosexual, nuclear families, and this can have unintended effects on families that do not conform to this norm.
In Sweden, the system is based on the idea that parents are willing and able to cooperate with each other, which may become problematic if they disagree on important issues. In cases of joint custody, each parent is entitled to half of the parental leave. If one of the parents does not want to take the allotted days of parental leave, the remaining days can be transferred to the other parent, but if the days are not transferred and the daddy quota is left unused, eight months of parental leave are automatically cancelled. This in turn means that the total parental leave taken for a child may not be enough to cover the period until the child starts in childcare, which may in turn affect the single parent financially. In Finland, only fathers who live with the child are entitled to parental leave. Thus, the system is not adapted to parents who do not live together.

\section{Nordic challenges}

Although the Nordic countries have come a long way when it comes to paid parental leave for all new parents, several important challenges remain. The Nordic region wants to invite others to a discussion on how these challenges can be effectively dealt with.

\section{Involved fatherhood}

Although the Nordic countries are moving in the right direction, mothers continue to take much more parental leave than fathers. The right to long and flexible periods of parental leave can become a gender equality trap if only women utilise it. How can men be encouraged to take more parental leave and become more involved in the care of children?

\section{Care of parents and other family members}

The ability of parents to combine parenthood with a career has been a central aspect of the 


\section{Share of parental leave taken by fathers}

per cent (2017)

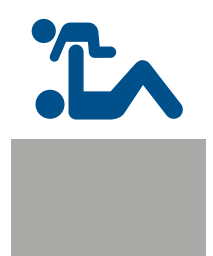

11 DENMARK

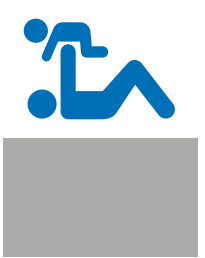

11 FINLAND

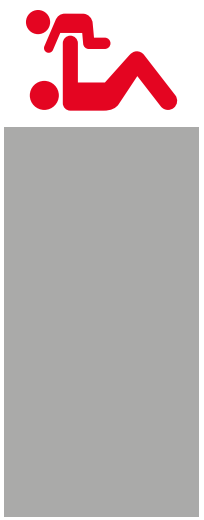

30 ICELAND

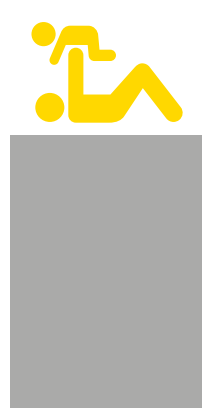

20 NORWAY

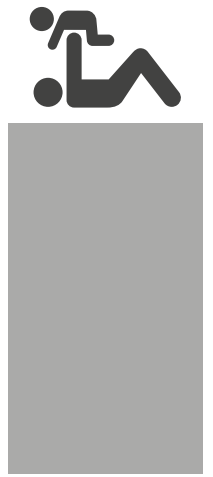

29

SWEDEN

In the Nordic countries, data on gender equality is gathered and evaluated. Access Nordic gender equality indicators here:

norden.org/statistics

Source: Nordic Statistics 2019

Nordic welfare model. One issue that has not received the same attention is that many adults (women in particular) take on the bulk of caring responsibilities for their ageing parents or other family members, in addition to their own children. What are the implications of this dual care role on women's participation in the labour market, particularly in the light an ageing populating and increasingly longer life expectancy?
Make the parental leave equally useful for non-traditional families

People in the Nordic countries live in a great variety of family constellations, including LGBTQ families and single-parent households. What are the unintended effects of current parental leave schemes on families that do not conform to the heterosexual, nuclear norm? 


\section{ICELAND: WORLD'S FIRST TRIPARTITE PARENTAL LEAVE}

\author{
In 2000, Iceland became the first country in the \\ world to introduce a parental leave model \\ consisting of three parts.
}

In the past, parents had been able to share six months of parental leave, but in practice, almost exclusively women used it. The reform included an extension of the parental leave from six to nine months per child, and of these, three months were reserved for one parent, three for the other parent, and three months to divide as they wished. The initiative had an immediate and powerful effect. Before the reform, less than one per cent of men in Iceland went on parental leave; after the reform, this skyrocketed to 87 per cent. Today, Icelandic fathers take a larger share of all parental leave than in any other Nordic country.

A quantitative study of new parents in Iceland, based on a longitudinal survey carried out in three parts, shows that the reform has had a positive impact on gender equality. The parents were asked how they divide their housework and domestic chores, childcare and income-generating work. The responses show that the division of paid work and domestic chores has become more equal since the new law was introduced, and that fathers who take the parental leave reserved for them become more involved in the care of their children.

Source: NIKK 2016

\section{GLOBAL TECH FIRMS ARE SETTING THE TREND}

\author{
Several global technology companies are \\ leading the way by offering their employees \\ paid parental leave.
}

One example is Spotify, the Swedish online music service giant, which since 2015 , grants six months paid parental leave to all full-time staff all over the world, including same-sex couples and adoptive parents. In addition to six-month parental leave, Spotify offers one-month flexitime, where parents can work from home. The policy has received a lot of attention in the United States, where Spotify has offices, and where larger private companies are only legally required to offer their women employees a minimum of 12 weeks of unpaid parental leave.

'We strongly believe in the connection between employee well-being and the development of the company. A healthy balance between work and family enables our workers to grow and accomplish great things both at work and at home,' says Katarina Berg, chief HR officer at Spotify.

She argues that Spotify comes from a Swedish tradition where a good work environment, gender equality and opportunities for parents to spend quality time with the most important people in their lives are considered important. Spotify is not the only multinational company that promotes the right to parental leave. In fact, this has become somewhat of a trend among the technology giants in Silicon Valley. Companies such as Microsoft, Facebook, Google and Apple now all offer their workers longer periods of paid parental leave than the statutory minimum, usually as one component of broader gender equality and inclusion HR policies, designed to recruit and retain talented employees from all backgrounds. 


\section{WHAT HAPPENS WHEN THE CHILDREN ARE SICK?}

\author{
Young children and in particular children in \\ childcare tend to get sick often. Consequently, \\ parents often have to stay home from work to \\ take care of a sick child.
}

Parents in all Nordic countries have the right to stay home with a sick child, although the exact rules vary. In Sweden and Norway, the right is protected by law. In the other countries, it is regulated jointly by the trade unions and employer organisations.

In Sweden, parents can stay home for a total of 120 days per child per year until the child turns 12 years old. On these days, they receive 80 per cent of their regular income up to a maximum amount.

Norwegian parents are entitled to 10 paid days per year until the child turns 12 years old. A single parent is entitled to 20 days. The compensation rate is $\mathbf{1 0 0}$ per cent of the lost income. In Denmark, the compensation rate and number of days a parent can stay home are regulated through collective agreements, often one to two days. Thus, there is no statutory right of absence in the case of a child's illness with the exception of force majeure cases. Finnish parents may stay home for four days per child if the child is younger than 10 years old, yet some employers voluntarily offer additional paid days off. In Iceland, parents have individual rights to stay home from work to take care of a sick child. However, they do not have a legal right to compensation. Still, many employers pay employees their regular pay when they need to stay home, and the exact rules and number of days are regulated in sector-specific collective agreements.

\section{DENMARK: BANKING ON INVOLVED FATHERS IN THE FINANCE SECTOR}

\author{
In Denmark, the right to parental leave is \\ regulated by law. However, the exact design \\ and details are largely up to the trade unions \\ and employer organisations to decide together.
}

All Danish trade unions have negotiated generous terms of parental leave in their collective agreements and continuous efforts are being made to further improve the conditions. The Financial Sector Union is one of the most progressive trade unions in the country, and has negotiated the right to 16 weeks of paid parental leave for fathers. The Financial Sector Union has about 40,000 members, all of whom work in banking and finance. Approximately 50 per cent of the members are men.

The result of the progressive collective agreement is clear. Since 2006 men's average use of parental leave has increased by 89 per cent in the financial sector in Denmark. In the same period white-collar male workers have on average increased their use of parental leave by 33 per cent, according to The Confederation of Danish Employers (DA).

'Here at the Financial Sector Union, we have made continuous improvements in the area. For example, parents can take the leave either as one long, uninterrupted period or as several shorter periods,' says Linda Faverholm, senior adviser at the Financial Services Union.

Source: Björnberg \& Ottosen 2013 


\section{Sources}

Björnberg, U., Ottosen, M.H. (Eds.), (2013). Challenges for future family policies in the Nordic countries. (13:38). Copenhagen: SFI - Danish National Centre for Social Research.

Forum for Mænds Sundhed, (2017). Fædres sundhed. En undersøgelse ved Forum for Mænds Sundhed.

Gíslason, I.V., and Björk, E.G. (Eds.), (2010). Föräldraledighet, omsorgspolitik och jämställdhet $i$ Norden. (TemaNord, 2010:595). Copenhagen: Nordic Council of Ministers.

Halrynjo, S., Kitterød R. H. (2016). Fedrekvoten - norm for fedres permisjonsbruk i Norden. En litteraturstudie. (2016:06). Oslo: Institute for Social Research.

Halrynjo, S., Teigen, M. (Eds.), (2016). Ulik likestilling i arbeidslivet. Gyldendal Akademisk.

Heilman, B., Levtov, R., van der Gaag, N., Hassink, A., Barker, G. (2017). State of the World's Fathers: Time for Action. Washington, DC: Promundo, Sonke Gender Justice, Save the Children, and MenEngage Alliance.

International Network on Leave Policies and Research, (2017). Leave Network Reports.

Nordic Information on Gender (NIKK), (2016). Därför stannar papporna hemma. Faktablad om föräldraförsäkringssystemen i Norden.

Nordic Statistics, (2019). Gender Equality Indicators.

OECD, (2017). PF2.1: Key characteristics of parental leave systems. OECD Family Database.
OECD, (2017). PF2.2: Use of childbirth related leave by mothers and fathers. OECD Family Database.

This brief is based on interviews with researchers. 


\section{About}

Nordic Solutions to Global Challenges is an initiative by the Nordic prime ministers to enable knowledge sharing and exchange under three pillars, namely: Nordic Green, the Nordic Gender Effect and Nordic Food \& Welfare. The initiative is part of the Nordic region's effort to promote progress towards the UN's Sustainable Development Goals through the Nordic Council of Ministers, the official arm of Nordic governmental cooperation. The Nordic Gender Effect at Work is the name of the prime ministers' flagship to promote gender equality as a goal in its own right, and as a prerequisite for decent work and economic growth.

This series of briefs was prepared by Nordic Information on Gender (NIKK). NIKK is a knowledge centre, which collects and disseminates Nordic research, knowledge and policy in the area of gender equality.

The briefs describe how the Nordic countries have facilitated women's participation in the labour market and promoted gender equality at large. The introduction provides an overview of the Nordic welfare model and a historical context for the solutions that have been developed in the Nordic region over time. There are four specific briefs, which outline policies and experiences on subsidised childcare for all, shared and paid parental leave, flexible work arrangements and measures to achieve gender balance in leadership and equal opportunities at work.

\section{Acknowledgements}

The Nordic Council of Ministers would like to acknowledge and give special thanks to the International Trade Union Confederation (ITUC) and UN Women for contributing with invaluable feedback to the briefs, and to the International Labour Organization (ILO) for the collaboration on the Global Dialogue on Gender Equality in the World of Work, which provided an invaluable foundation for the series.

Thanks to all contributors including author Ida Måwe, flagship project initiator Julia Fäldt Wahengo, lead editors Line Christmas Møller, Elin Engström and Anna Rosenberg, as well as Ulrika Jansson, Kajsa Widegren, Maria Grönroos, Josefine Alvunger, Sanna Schiller, Ned Lawton, Ulla Agerskov, Frida Thomassen, Idah Klint, Sigtona Halrynjo, Johanna Lammi-Taskula, Ingólfur V. Gíslason, Ulla Björnberg, Tine Rostgaard, Charlotta Niemistö, as well as the flagship steering committee and the Nordic Committee of Senior Officials for Gender Equality.

\author{
For more: \\ norden.org/nordicgendereffect and nikk.no
}


Nordic Council of Ministers

Nordens Hus

Ved Stranden 18

DK-1061 Copenhagen

www.norden.org

Promoting gender equality at work is not only a matter of rights; it is the smart thing to do from the perspective of inclusive growth. The Nordic region is a case in point, as it has come to represent the 11th largest economy in the world, not despite policy commitments to gender equality and social justice, but because of it. The Nordic countries have robust economies and good living conditions, where both women and men have high labour force participation rates. However, the gender pay gap is persistent and occupational segregation continues to hinder gender equality.

The Nordic Gender Effect at Work briefs share the collective Nordic experience in investing in gender equality including parental leave, childcare, flexible work arrangements, leadership and equal opportunities at work, and seek to make further progress through cooperation. 